\title{
Methodological guidelines in the elaboration of the evaluation tests for the end of the fundamental acquisitions stage
}

Denisa Moldovan \& Mușata Bocoṣ 


\title{
Methodological guidelines in the elaboration of the evaluation tests for the end of the fundamental acquisitions stage
}

\author{
Denisa Moldovan ${ }^{a^{*}}$, Mușata Bocoș ${ }^{b}$ \\ ${ }^{a}$ Doctoral School "Educational, Reflection, Development", Babeș-Bolyai University, 7 Sindicatelor Street, Cluj-Napoca, 400029, Romania \\ ${ }^{b}$ Faculty of Psychology and Educational Sciences, Babeș-Bolyai University, 7 Sindicatelor Street, Cluj-Napoca, 400029, Romania
}

*Corresponding author: denisamonicaungurasan89@gmail.com

\section{Abstract}

\section{Keywords:}

methodology, National

Evaluation, fundamental acquisitions stage, competence.
At the end of the fundamental acquisitions stage, respectively of the second grade, students from the Romanian education system go through an evaluation process of the general and specific school competences formed in the first years of school. In the first part of this paper we approach some aspects and theoretical perspectives associated with docimology. Thus, we build a schematic theoretical-applicative framework, which we promote in order to facilitate a global understanding of the didactic evaluation process in general and of the didactic evaluation at the level of the primary classes, in particular. At the same time, we approach didactic evaluation from the perspective of the current national curriculum and the relevant prospective and praxiological directions in the educational activity. We highlight the absolute need to emphasize the interdependence relationships between the didactic project phase and the evaluation process, in the context of a competence-centered curriculum. Subsequently, we present validity criteria, design stages and relevant sections of some original assessment tools, which have the potential to highlight the students' results in terms of competences.
Zusammenfasung

Schlüsselworte: Methodik,

Kompetenzprüfung, grundlegende Erwerbsphase, Kompetenz
Am Ende der grundlegenden Erwerbsphase bzw. der zweiten Klasse durchlaufen die Schüler des rumänischen Bildungssystems einen Bewertungsprozess der in den ersten Schuljahren gebildeten allgemeinen und spezifischen Schulkompetenzen. Im ersten Teil dieser Arbeit werden einige Aspekte und theoretische Sichten im Zusammenhang mit der Dozimologie erörtert. So bauen wir einen schematischen theoretisch-anwendungsbezogenen Rahmen auf, den wir fördern, um ein globales Verständnis des didaktischen Bewertungsprozesses im Allgemeinen und insbesondere der didaktischen Bewertung auf Ebene der Grundschulklassen zu ermöglichen. Gleichzeitig gehen wir die didaktische Evaluation aus der Perspektive des aktuellen nationalen Lehrplans und der relevanten zukünftigen und praxeologischen Richtungen in der pädagogischen Tätigkeit an. Wir unterstreichen die absolute Notwendigkeit, die Wechselbeziehungen zwischen der didaktischen Projektphase und dem Evaluierungsprozess im Kontext eines kompetenzzentrierten Lehrplans zu betonen. Anschließend werden Validitätskriterien, Entwurfsphasen und relevante Abschnitte der selbstentwickelten Bewertungsinstrumente vorgestellt, die das Potenzial haben, die Ergebnisse der Schüler in Bezug auf ihre Kompetenzen hervorzuheben.

\section{Introduction}

The didactic evaluation is a complex process which involves permanent actions of measuring the value of the results of the education system and evaluating the conditions in which the educational activity is carried out. According to Bocoș \& Jucan (2019) the evaluation represents a subsystem of the education process, through which its efficiency is measured and appreciated respectively the level of attainment of educational purposes. Properly applied from a docimological point of view, these approaches contribute to increasing teaching efficiency and to making decisions to improve and perfect the entire teaching-learning-evaluation process, thus fulfilling a regulatory role.

The stage of fundamental acquisitions ends with a series of evaluation activities. At the national level, certain standardized tests are administered for the disciplines: Mathematics and Romanian Language, with the reading and writing sections. We provide an inventory of methodological benchmarks that we have followed in the elaboration of evaluation tests intended to prepare students for the National Evaluation EN II. These original instruments are contained in a curricular auxiliary published by the author, in collaboration with other educational partners, and approved by the Romanian 
Ministry of National Education. We intend to make known the methodological guidelines followed, to be used by all teachers for the elaboration of the assessment tools in the classroom. At a general level, our methodological course followed three main directions, which we will explain and exemplify during the present paper:

- the stages of designing the evaluation tests;

- the elaboration of the samples for the assessment of the reading-writing competence;

- the elaboration of the samples for the assessment of the mathematical competence.

2. Steps required to be followed in the elaboration of evaluation tests

\subsection{Legal classification of the didactic evaluation process and elaboration of evaluation tests}

First of all, the didactic evaluation and the elaboration of the evaluation instruments must have a legal basis. The Low of National Education in Romania (Legea educației naționale nr. 1/ 2011) stipulates in Chapter V. Evaluation of learning outcomes, Section I. General provisions regarding evaluation, the following articles to be observed and respected:

- Art.71.-(1) The purpose of evaluation is to guide and optimize learning.

- Art.72. - (1) The assessment is focused on competences, offers real feedback to the students and is the basis of the individual learning plans.

The elaboration of the evaluation tests implies an effort of complex comparison of the results of the instructive - educational activity on three distinct, but complementary levels. The creators of evaluation tools must anticipate to what extent these instruments will be able to evaluate:

- the quality, by comparing the results with the proposed educational purposes;

- the efficiency, by comparing the results with the resources that have been used;

- the progress, by comparing the present results with the previous results.

\subsection{Elaboration of evaluation tests through permanent reporting to competency-focused curriculum}

The didactic approach must consider the current curricular paradigm and start from a curricular design focused on competences. Complementary to the competence-centred teaching-learning process, also the assessment must be carried out in the most authentic and real conditions, connected with reality. The evaluation tests developed, both during and especially for the end of the stage of fundamental acquisitions, must highlight the results of the students in terms of competences.

\subsection{Competence-focused didactic assessment}

By their specificity, the school evaluation context should allow students to demonstrate the achievement of current performances and of the general and specific school competences targeted at national level. After the first three years of school, students are able to demonstrate a certain school competence as long as they are supported to develop and prove their readiness to:

- $\quad$ select and use resources;

- effectively organize their prior experience;

- properly use their past benefits.

\subsection{Criteria for the elaboration of the evaluation tests}

Both at the macro-educational level, for the National Evaluation, as well as at the micro-educational level, in the evaluation activity in the classroom, the creators of the evaluation instruments must ensure that those tools meet the following criteria simultaneously:

- validity;

- fidelity;

- objectivity;

- applicability;

- sensitivity.

We also insist that the evaluation tests developed should be rigorously checked and, before administering them, anticipate whether they:

- provide relevant information on learning outcomes;

- are in functional relation with the educational objectives to be evaluated; 
- have the quality to achieve the purpose for which they were developed;

- integrate various types of items.

\subsection{The steps of designing the evaluation tests for the end of the fundamental acquisitions stage}

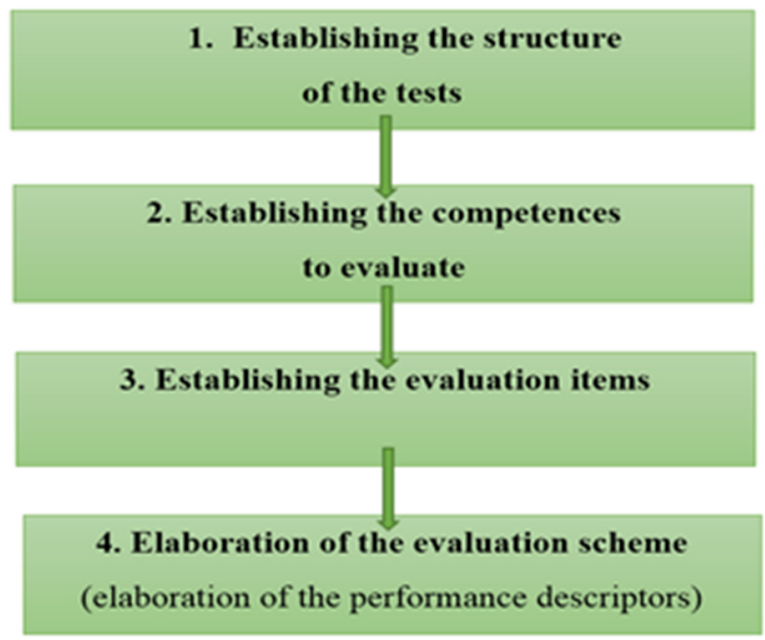

Figure no. 1. The steps of designing the evaluation tests intended to prepare students for the National Evaluation EN II in Romania

\section{Elaboration of the tests for the evaluation of the reading and writing competence}

\subsection{Developing the competence of reading and writing in primary school}

The competence of communication in the native language (in our case, in the native language or in the language of the state) begins at the level of the first three years of school with the competence of reading and writing. This competence is a linguistic instrument necessary for all subsequent acquisitions. The reading-writing in Romanian ensures the use of the tools of intellectual work in order to train the students in the communication act, the interaction with their peers in real and diverse communication situations, anchoring the students in the realities of the time they are living. At national level, the main capacities targeted at the end of the second grade by the assessment for the fundamental competence of reading and writing are mentioned in Programa școlară: Comunicare în limba română (OMEN nr. 3418/ 19.03.2013):

- extracting essential information from a read text;

- correct and expressive reading, on its own rhythm, of a text;
- writing correct text from a lexical and a grammatical point of view;

- writing texts in compliance with the conventions of written language, correct page placement and legible writing.

\subsection{Evaluating the competence of reading and writing in primary school}

In the elaboration of the evaluation tests for students' EN II preparation, specific tasks were designed so as to allow them to practice and to demonstrate these capacities. We intended to help students to develop and test their competence of reading and writing by creating some contexts that facilitate the actions of decoding and using written texts and the reflection on the specific information for different fields of knowledge and/ or regarding the daily reality. In the particular case of developing reading competence one must consider some important factors regarding the texts included in the evaluation tests: the reading situation (personal, educational, occupational, public, scientific), the type of text, the structure of the text and the characteristics of the items (Pălășan, 2013).

\subsubsection{The format of the texts chosen or created to be included in the reading evaluation tests}

We have adapted and applied schematic representations proposed by Norel \& Sâmihăian (2006, pp. 48-49):

the narrative sequence

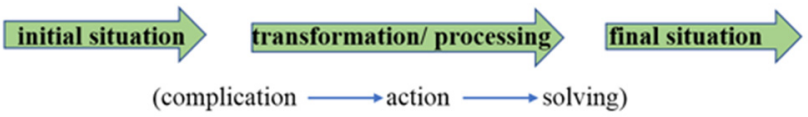

Figure no. 2. The format of narrative texts/ sequences included in the evaluation tests intended to prepare students for the National Evaluation EN II in Romania

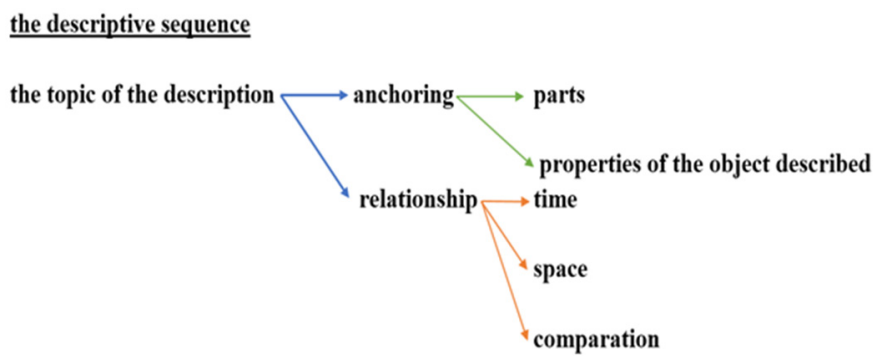

Figure no. 3. The format of descriptive texts/ sequences included in the evaluation tests intended to prepare students for the National Evaluation EN II in Romania 
the argumentative sequence

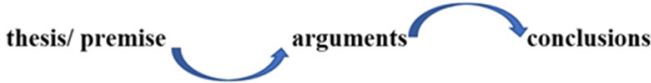

Figure no. 4. The format of argumentative texts/ sequences included in the evaluation tests intended to prepare students for the National Evaluation EN II in Romania

\section{the explanatory sequence}

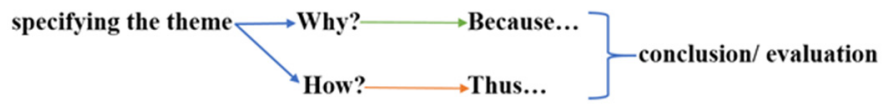

Figure no. 5. The format of explanatory texts/ sequences included in the evaluation tests intended to prepare students for the National Evaluation EN II in Romania

the dialogue sequence

fatigue sequence
(opening) transactional sequences $\longrightarrow \begin{gathered}\text { fatigue sequence } \\ \text { (closing) }\end{gathered}$

Figure no. 6. The format of explanatory texts/ sequences included in the evaluation tests intended to prepare students for the National Evaluation EN II in Romania

\subsubsection{Criteria for selecting the appropriate texts for the reading evaluation tests}

In order to demonstrate, in the assessment situation, the skills acquired by the students, the texts for the reading tests must be selected so as to meet the following criteria:

- to cover as wide a range of types of texts as possible to stimulate students' interest in reading;

- to be authentic, of interest, possible to be encountered in everyday life;

- to constitute a significant and stand-alone cut-off of a maximum of 125 words, which will enable the text message to be understood and the formulated assessment to be met;

- to be included in the benchmarks specified by the national curriculum;

- to be texts at first sight, not studied in class.

\subsubsection{The structure of the writing evaluation tests}

The level of students' competence in writing is verified by applying specific tests consisting of two evaluation subjects/ items. The first one requires functional writing: writing a note, starting from a particular situation that has been described/ a hypothetical problematic situation. The second subject requires imaginative writing: writing a short original text, starting from a concrete situation that has been described and based on support questions.

Example for the first subject/ item: In two days you will go to a school camp with your classmates, but you have not yet packed your luggage. You forgot to buy a necessary cap and a lantern. Write a note to your mother to remind her of the camp and ask her to buy you the items you need. Check if you have complied with the requirement, that you have written the date and the starting formula and that you have signed the note (Ungurășan, 2017, p. 58).

Example for the second subject/ item: It's been a week since you came back from camp with your classmates. Once you get home, you want to tell your parents the most important experiences you have experienced there. Write a text consisting of five sentences, in which you provide details about the camp you attended, answering the following questions: Where did you stay? What interesting activities did you do? Who did you make friend with? How was the weather? How did you feel? (Ungurășan, 2017, p. 59).

\section{Elaboration of the tests for the evaluation of the mathematical competence}

\subsection{Developing the mathematical competence in primary school}

During the first three years of school teachers must develop students' ability:

- to identify and understand the role played by mathematics in the world;

- to make well-founded judgments;

- to use mathematics and to engage in the approach of mathematics in ways that respond to the need of individual life, as constructive, responsible and reflective citizen.

\subsection{Evaluating the mathematical competence in primary school}

The design of the evaluation tests for mathematics must be done so that the students are able to demonstrate their ability to apply knowledge to problem solving situations from the real world. The assessment tools created must also appeal to the previous experience of the students, 
which was assimilated into non-formal or informal contexts.

Both in the process of teaching and developing the mathematical competence, respecting the national curriculum, Programa școlară: Matematică și explorarea mediului (OMEN nr. 3418/ 19.03.2013), as well as in the evaluation one, it is essential to:

- build a problem situation specific tot the context of real life/ world;

- organize the problem in accordance with the mathematical concepts;

- gradually cut the reality, which involves actions such as: making assumptions about which of the attributes of the problem are important and then generalizing and formalizing the problem;

- solve the mathematical problem;

- give meaning to the mathematical situation in terms of a life situation.

In our original mathematics tests, a life situation/ context is presented at the beginning. All the evaluation items (objective, semi-objective and subjective) are built around that situation. We recommend that the problem situation around which the evaluation items are created should be concrete and real.

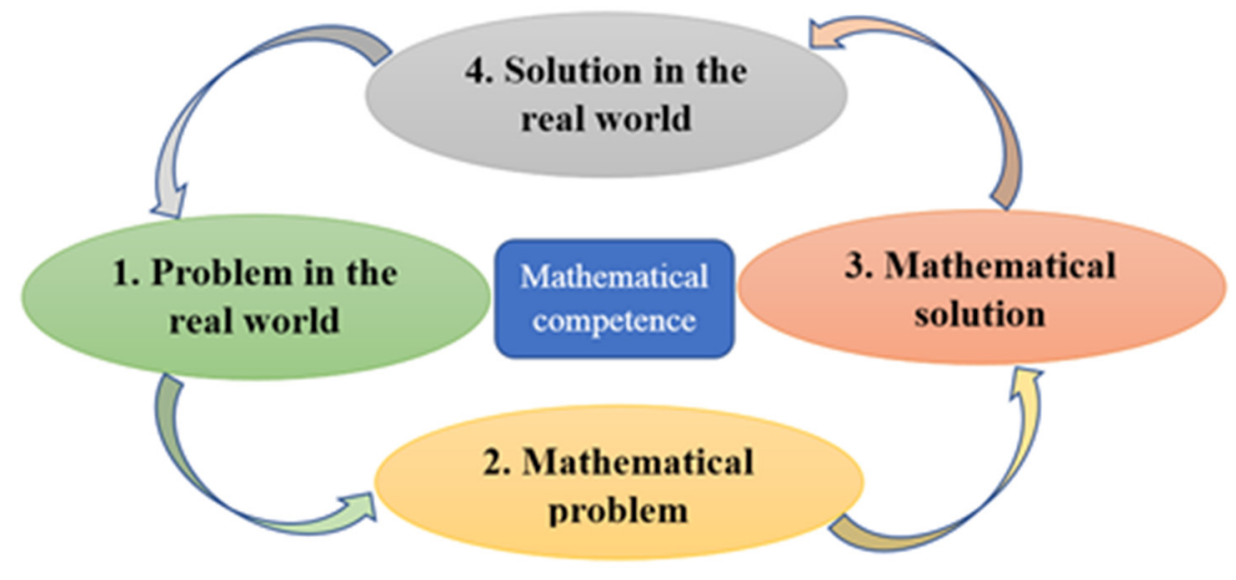

Figure no. 7. The evaluation of mathematical competence through items that require problem solving

Example of a math test item:

Life situation - The Children's Cinema has released posters of the films that will be playing for a week.
Andrew and his friends were late for the movie and the lights went out.

Requirement - Look at their tickets and help them find their seats in the movie theatre. Discover the rule and fill the blanks with the missing numbers.

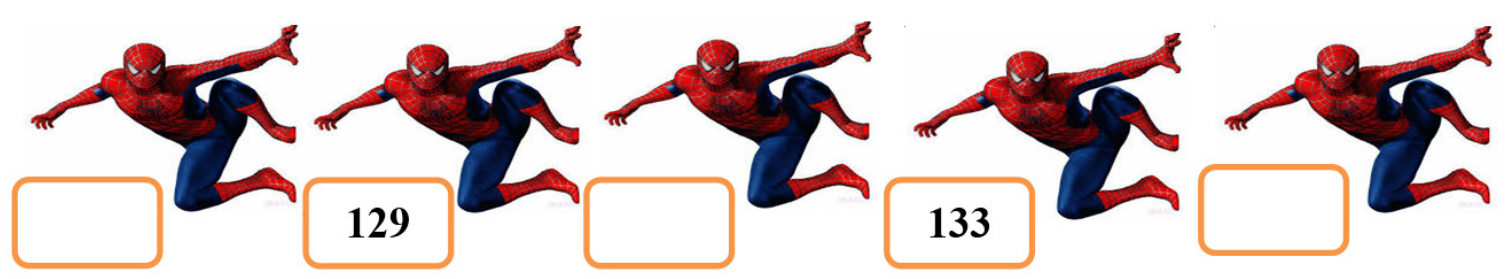

Figure no. 8. Semi-objective item for the evaluation of mathematical competence through problem solving (Ungurășan, 2017, p. 102). 


\section{Conclusions}

The elaboration of evaluation tools designed to prepare students for the end of the fundamental acquisitions stage requires a solid documentation from a legal, pedagogical and a methodological point of view. The assessment items must be permanently related to the specific or general competences that are developed to the students up to this age level. The evaluation tasks must be as diverse as possible and involve the students in the cognitive processes that allow them to demonstrate the competences acquired by the end of the second grade and to optimize their school learning.

\section{Authors note:}

The authors have equal contributions to this article.

Denisa Moldovan is a Ph.D. student at Faculty of Psychology and Sciences of Education, Babeș-Bolyai University, Cluj-Napoca, Romania. She graduated a BA programme in Pedagogy of primary and preschool education in 2011 and a MA degree in School counselling and psycho-pedagogical assistance in 2013. Her research interest is reflected in several articles published as a result off attending national and international conferences. She is a primary school teacher at "George Bariţiu" National College, Cluj-Napoca, Romania, since 2012. She publishes collections of tests designed to prepare students for national assessments, since 2017.
Muşata Bocoş is University Professor and Ph.D. Coordinator at the Faculty of Psychology and Sciences of Education (Babeș-Bolyai University, Cluj-Napoca, Romania). She has obtained a Ph.D. in Educational Sciences in 1997 at Babeș-Bolyai University. Her research interests are reflected in a series of studies and articles published in important national and international journals. Her teaching activity covers several domains such as the theory and methodology of curriculum, general didactics, and educational research.

\section{References}

Bocoş, M., Jucan, D. (2019). Teoria şi metodologia instruirii. Teoria şi metodologia evaluării. Repere şi instrumente didactice pentru formarea profesorilor, ediţia a IV-a, revizuită. Pitești: Editura Paralela 45.

Norel, M. \& Sâmihăian, F. (2006). Didactica limbii și literaturii române. București: MEC.

Pălășan, T. (coord.). (2013). Ghid de elaborare a subiectelor de evaluare a competențelor fundamentale scris-citit și matematică la finalul clasei a II-a. Centrul Național de Evaluare și Examinare (CNEE).

Ungurășan, D.M. (2017). Evaluarea Națională 2017. București: Editura Delfin.

*** Legea Educaţiei Naţionale nr. 1/ 2011, cu modificările şi completările ulterioare. Available at: http://legeaz.net/legeaeducatiei-nationale-1-2011/ (accessed at 10.11.2019).

*** Programa școlară: Comunicare în limba română. (2013). OMEN nr. 3418/ 19.03.2013. București: Ministerul Educației Naționale.

*** Programa școlară: Matematică și explorarea mediului. (2013). OMEN nr. 3418/ 19.03.2013. București: Ministerul Educației Naționale. 